\title{
The impact of market orientation on the performance of MSMEs operating in technology parks: The role of market dynamism
}

\section{Anna Wójcik-Karpacz ${ }^{1}$ iD, Jarosław Karpacz ${ }^{2}$ iD, Joanna Rudawska ${ }^{3}$}

\begin{abstract}
Purpose: The purpose of this article is to identify the role of market dynamism in the relationship between market orientation and the performance of micro, small, and medium enterprises (MSMEs) operating in technology parks (TPS) in Poland. Methodology: The two methods used for performing the quantitative empirical research are CAWI and PAPI. The research sample included MSMEs operating in technology parks in Poland. The article is the answer to the needs for systematic research of models between market orientation and firm performance. Findings: The research findings provide an insight into the level of market orientation and performance of the analyzed MSMEs operating in technology parks in Poland. It was found that MSMEs in the research sample were not a homogeneous group in this respect. It has been proven that market orientation is a significant stimulant of firm performance, while market dynamism has not been classified as a moderator of the market orientation-firm performance relationship. Implications for theory and practice: This study contributes to strategic management by identifying the key role of market orientation for enterprises wishing to benefit from this type of strategic orientation. The important role of the predictor - market orientation in shaping the results of micro, small and medium-sized enterprises operating at TPs in Poland has been proven. In practice, this means that increasing the level of market orientation is conducive to increasing positively assessed financial performance. Originality and

1 Anna Wójcik-Karpacz, Full Professor, Faculty of Law and Social Science, The Jan Kochanowski University in Kielce, Uniwersytecka 15, 25-406 Kielce, Poland, e-mail: anna.wojcik-karpacz@ujk.edu.pl (ORCID: https://orcid.org/0000-00026303-6778).

2 Jarosław Karpacz, Full Professor, Faculty of Law and Social Science, The Jan Kochanowski University in Kielce, Uniwersytecka 15, 25-406 Kielce, Poland, e-mail: jaroslaw.karpacz@ujk.edu.pl (ORCID: https://orcid.org/ 0000-00017315-2855).

3 Joanna Rudawska, Ph.D., Faculty of Law and Social Science, The Jan Kochanowski University in Kielce, Uniwersytecka 15, 25-406 Kielce, Poland, e-mail: joanna.rudawska@ujk.edu.pl (ORCID: https://orcid.org/0000-0003-1484-8283).
\end{abstract}


value: Our research carried out at MSMEs operating in technology parks in Poland enriches and supplements knowledge about market orientation as a phenomenon of universal character because it also applies to smaller sized business organizations.

Keywords: market orientation, market dynamism, firm performance, technology park, micro, small, medium enterprises, MSMEs

\section{INTRODUCTION}

Small enterprises are important for most economies (Zakrzewski \& Skowrońska, 2019). In general, small- and medium-sized enterprises (SMEs) and micro-enterprises are indicated as important sources of job creation and income generation in market economies, and this honorable role is played especially by those micro, small, and medium enterprises (MSMEs) which are growth-oriented (Rigtering, Kraus, Eggers, \& Jensen, 2014; Harbat et al., 2018). Considering the constantly changing nature of the economic environment, these enterprises are continuously striving to take new opportunities in the market, so that they can identify growth paths and develop well. Growth is also a condition of survival for young and small businesses, as growing firms are found to be less vulnerable to failure than non-growers (Gancarczyk \& Zabala-Iturriagagoitia, 2015). Strategic orientations of enterprises describe the trends and decision-making principles of enterprises that direct their actions and generate behaviors with the intention of achieving better organizational performance in the markets in which they conduct economic activities (Hakala, 2011). Development of strategic orientations in enterprises may therefore have a significant impact on organizational performance (Wales, Beliaeva, Shirokova, Stettler, \& Gupta, 2020). That is why enterprises' strategic orientations are the object of scientific research with regard to their relationships with organizational performance ( $\mathrm{Mu}$, Thomas, Peng, \& Di Benedetto, 2017). Previous research has distinguished several types of strategic orientations, including market orientation (Hakala, 2011; Kirca, Jayachandran, \& Bearden, 2005). Market orientation (MO) reflects the degree to which enterprises rely on maximizing customer satisfaction and loyalty as their organizing principle (Gnizy, Baker, \& Grinstein, 2014). Market orientation is a phenomenon of universal character and concerns every size of organisation. However, the literature indicates that previous research was focusing on the role of strategic orientations in large multinational corporations (Baker \& Sinkula, 2005; McKenny, Short, Ketchen Jr., Payne, \& Moss, 2018), rather than in micro- or small- and medium-sized enterprises (Kara, Spillan, \& DeShields, 2005; Michna \& Kmieciak, 2012).

Thus, there is still a deficit of empirical research on some groups of enterprises, and MSMEs operating in technology parks in Poland are 
undoubtedly among them (Wójcik-Karpacz, 2019). Therefore, the aim of this article is to identify the role of market dynamism in the relationship between market orientation and performance of MSMEs operating in technology parks in Poland. Explaining these issues is essential in order to be able to treat market orientation as a strategic organizational factor shaping firm performance, including different environmental conditions.

The article is the answer to the needs for systematic research of models between market orientation and firm performance. The subject matter of the article forms part of the broader trend of research on discovering the role of market dynamism while analyzing the effects of market orientation. The two methods used for performing the quantitative empirical research are CAWI and PAPI. The research sample included micro-, small- and medium-sized enterprises (MSMEs) operating in technology parks in Poland. Enterprise size is defined as the number of employees.

\section{LITERATURE REVIEW}

\section{Theoretical framework and hypothesis development}

\section{Conceptualization of market orientation in literature}

Previous research has recognized two main conceptualizations of market orientation (Gupta, Gizem, \& Dutta, 2019). One of the main definitions of $\mathrm{MO}$ is the one proposed by Kohli and Jaworski (1990), who define it as the organization-wide generation of market intelligence pertaining to current and future customer needs, dissemination of the intelligence across departments, and organization-wide responsiveness to it. In the extant literature, market orientation has been pinpointed as a part of organizational behavior, a facet of organizational culture, a firm resource, or a firm capability (ipek \& Bıçakcıoğlu-Peynirci, 2020). Market orientation is closely intertwined with market learning; such that market-oriented firms regularly gather data about their external stakeholders and they convert this information into market offerings with superior customer value. Additionally, firms with high market orientation possess exceptional market sensing, customer linking, and channel bonding competencies, which are supported by effective management practices (Ijpek \& Bıçakcıoğlu-Peynirci, 2020). To be implemented successfully, market orientation requires enterprises to proactively acquire, disseminate and rely on market information when developing marketing strategies and tactics. Kohli and Jaworski (1990) believe that MO relates to organizationwide generation and dissemination of market information, and accompanies 
organizational responses (Kohli \& Jaworski, 1990). This conceptualization of $\mathrm{MO}$ was adopted in this research. Knowledge is one of the key assets that needs to be properly managed (Soniewicki \& Paliszkiewicz, 2019). By empowering, disseminating, and using customer and market information, MO enables enterprises to tailor their activities to target markets, anticipate and respond to customer needs, as well as build competitive advantage (Atuahene-Gima, Slater, \& Olson, 2005). Based on the scientific literature review, it is obvious that knowledge is one of the key factors affecting especially market choices, entry modes (Wach, 2017). Customers are more satisfied with products and services provided by a market-oriented enterprise and their loyalty to such an enterprise increases (Wales et al., 2020). The second important conceptualization presented in the literature is the one proposed by Narver and Slater (1990). These scientists combine dimensions of customer orientation, competitor orientation, and inter-functional coordination. MO refers to strategic inclination and enterprise-level activities directed at the generation of superior value for customers. A market-oriented enterprise is one that most effectively and efficiently creates the necessary behaviors for the creation of superior value for buyers and, thus, continuous superior performance for the enterprise (Narver \& Slater, 1990).

Market orientation is perceived as organizational resources (Hult, Snow, \& Kandemir, 2003), and more recently - as dynamic capabilities. Market orientation provides the firm with market-sensing, customer-linking, and channel-bonding capabilities (Abbua \& Gopalakrishna, 2021). This orientation has been labeled as DCs (Barreto, 2010) because the focus on customers, competitors and the external market environment imbues enterprises with the ability to make informed, proactive adjustments to capabilities (Gnizy, Baker, \& Grinstein, 2014). Therefore, the undertaken subject matter is part of the enterprise's resource-based view (RBV) and dynamic capabilities view (DCV). The basic assumption of the enterprise's resource-based view (RBV) is to strive to achieve competitive advantage of large enterprises and MSMEs (Hessels \& Parker, 2013). However, RBV does not explain how enterprises maintain competitive advantage in changing and uncertain environments. The DCs framework is an extension of the enterprise's resource-based view (RBV) (Barney, 1991) to fill out these gaps. Through dynamic capabilities, companies are able to sense and seize new business opportunities and to reconfigure the company. The bare existence of dynamic capabilities allows changing business models more proficiently and, thus, tapping the potential of new business opportunities (Freiling, 2015). 


\section{Relationships of market orientation with firm performance in the context of market dynamism - research model}

Market dynamism, forcing enterprises to adapt themselves to the imposed rules of the game, means that these enterprises, being subject to the influence of internal and external forces, are in a state of permanent change and transformation. The process of shaping capacities and ways of behavior may not be treated as a one-time action, being an ex-post reaction of a given enterprise to changes in the environment, but should be a process allowing for continuous anticipation of change (Cyfert \& Krzakiewicz, 2017). A company's capacity to achieve its aims calls for successful adaptation to the changes occurring in its environment as well as for the creation of its own solutions (Bitkowska, 2020).

According to DCV, market orientation facilitates (re)configuration of other performance-related capabilities and behaviors, which are fundamental to evaluation of economic operations. Enterprises with strong MO are likely to be adept at effectively developing and launching innovations in established products and market. If this orientation is weak, it may be seen as a threat that can make it difficult for enterprises to maintain expected business results in new and changing conditions, which generates chances and threats. Nowadays, the general trend in the business environment is to shorten the product's life and business model cycle (Dyduch, 2017). Thus, future profit streams from existing operations are unsure, and the companies have to seek new opportunities all the time.

For this reason, companies should modify, reject or achieve the resources and redesign their business models (Li \& Liu, 2014). Like large enterprises, MSMEs need to focus on the market. However, MO is different in SMEs in comparison to large enterprises. The differences result from SMEs' characteristics such as small size, informal organization structure, and being close to the market (Kmieciak \& Michna, 2012).

Weak market orientation may be more painful for MSMEs, which, unlike large enterprises, have no resources to cover potential business failures, and especially continuous ones, which may reduce their performance. There were controversial research findings on environmental dynamism and its determining of the effects of operational and dynamic capabilities. The results indicate that operational and dynamic capabilities (i.e., MO) have different performance effects in high-dynamic and low-dynamic environments. The discussion on operational effects and dynamic capabilities (i.e., MO) in different market conditions still requires better theorizing and empirical research on the implications of market dynamism (Petrus, 2019). Literature studies show that insufficient research has been carried out on the MSMEs' 
group in the field of moderating the market orientation-firm performance relationship in the context of market dynamism, while these issues are universal in terms of the size of enterprises (Michna \& Kmieciak, 2012). The discussion on operational effects and dynamic capabilities in different market conditions still requires better theorizing and empirical research on the implications of market dynamism (Karna, Richter, \& Riesenkampff, 2016). Therefore, it was decided to analyze the influence of market dynamism, describing the functioning of enterprises on their performance in the context of dynamism of the market in which these enterprises operate. It was assumed that market orientation could show different patterns at different levels of market dynamism (Kamasak, Yavuz, \& Altuntas, 2016; Petrus, 2019). To recognize the implications of market dynamism on the market orientationfirm performance relationship. In this research, market dynamism was understood as the rate of change of various elements in the market in which a given enterprise operates (Wang, Senaratne, \& Rafiq, 2015). It was expected that market dynamism covering three dimensions, i.e. speed of change in technology and competition, unpredictability of change in technology and competition, and uncertainty of customer behavior, was the moderator of the market orientation-firm performance relationship. That is why the following hypothesis has been put forward:

H1: Market dynamism moderates the market orientation-firm performance relationship; the positive effect of market orientation on firm performance is likely to be stronger under high market dynamism than under low market dynamism.

The above discussion is summarized by the research model presented in Figure 1. It shows the analyzed constructs and expected relationships.

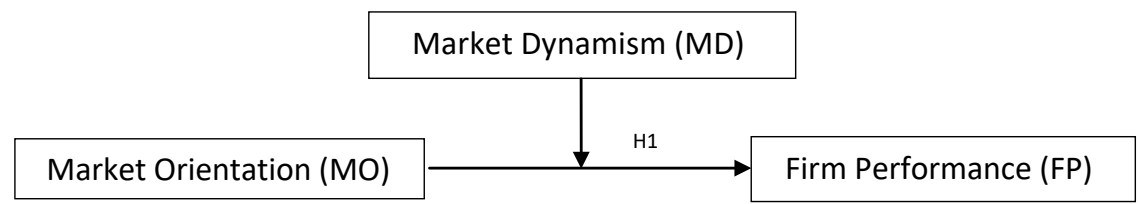

Figure 1. The research model and hypothesis

The object of research is market dynamism, which may be a moderator and better explain the analyzed market orientation-firm performance relationship. Therefore, it was decided to continue research efforts related to the analysis of the market orientation-firm performance relationship in the 
conditions of existing intermediary variables affecting this relationship. That is why the hypothesis was verified by a linear regression model in the next step.

\section{METHODOLOGY AND RESEARCH METHODS}

This research is based on a survey of MSMEs, including micro-, small- and medium-sized enterprises (ACT of 6 March 2018 - Entrepreneurs' Law, Journal of Laws of 2019, item 1292, art. 7). Using the contact details provided on technology parks' websites or on the websites belonging to their tenant enterprises, a list of 1568 MSMEs (including self-employment) operating in the technology parks (TPs) was developed. At this stage of the research, it was impossible to determine the structure of these enterprises (general population) according to the size of enterprises measured by the number of employees. As a result, the survey covered all identified enterprises operating in technology parks in Poland. The overall research was carried out from March 2017 to December 2018. The empirical research was conducted using the PAPI (Paper over Pencil Interview) and CAWI (Computer Assisted Web Interviews) techniques. Sending e-mails (using the CAWI method) to respondents was preceded by informing the managing directors of technology parks in Poland about conducted studies and asking them to disseminate this information to tenant enterprises to authenticate this empirical research. Technology parks' managing directors were also asked to support the distribution of questionnaires among tenant enterprises through internal communication systems, i.e. tenant enterprises' e-mail databases, newsletters, Intranet, social media groups such as Facebook, or appointing employees to distribute paper questionnaires (using the PAPI method). Enterprises' owners/managers served as respondents due to their knowledge of market orientation and firm performance being achieved as a result of conducting economic activities. Initially, 225 enterprises took part in the survey. The overall return of questionnaires was $14 \%$. At this stage of the research, data obtained from the respondents on the size of the analyzed enterprises were also enabling the exclusion of both self-employed entrepreneurs and large enterprises from the research group because they were not the objects of the research. Therefore, the effective research sample was much smaller (182 enterprises), being reduced by large enterprises ( 5 enterprises) and self-employed entrepreneurs (38 enterprises) that were initially included in the overall research sample. Thus, the effective return of questionnaires subject to further statistical analysis was $12 \%$.

The applied market orientation measures were dedicated to enterprises employing at least one employee (Gnizy, Baker, \& Grinstein, 2014). Hence, 
the research sample did not include self-employment that is a form of selfemployed work as an independent, non-agricultural economic activity as part of a one-person enterprise which does not employ employees (Lasocki \& SkrzekLubasińska, 2016; Zakrzewski \& Skowrońska; 2019). This means that those micro enterprises that had not been employing any employees were excluded from the research. This article presents only a part of the research project results among these enterprises at that time. Data showing the structure of the research sample by size of the enterprises are shown in Table 1.

Table 1. Structure of the research sample according to the size of enterprises

\begin{tabular}{lll}
\hline $\begin{array}{l}\text { Size of enterprises } \\
\text { (according to the number of employees) }\end{array}$ & $\begin{array}{l}\text { Number } \\
\text { of enterprises }\end{array}$ & $\%$ \\
\hline Micro-enterprises (from 1 to 9 employees)* & 93 & 51.1 \\
\hline Small enterprises (from 10 to 49 employees) & 68 & 37.4 \\
\hline $\begin{array}{l}\text { Medium enterprises (from } 50 \text { to } 249 \\
\text { employees) }\end{array}$ & 21 & 11.5 \\
\hline In total & 182 & 100.0 \\
\hline Note: * except for self-employment. & &
\end{tabular}

More than half $(51.1 \%)$ of the analyzed enterprises were microenterprises in the research sample in which employment did not exceed nine persons (except for self-employment). Small enterprises constituted $37.4 \%$ of all enterprises belonging to the research sample. Every tenth enterprise (11.5\%) belonged to the group of medium-sized enterprises. The methods of statistical description and inference were used to analyze the empirical data. First, Cronbach's Alpha test was used because it measures the internal consistency of the questionnaire. There were three theoretical constructs subjected to the analysis of reliability (market orientation, firm performance, and market dynamism). All variables in the model were latent.

Despite the fact that the reliability of scales used in the questionnaires had previously been analyzed by their authors, the questionnaires used in this empirical research were verified once again. The purpose of testing the reliability of scales, in this case, was to verify whether the reliability of the questionnaire, in the analyzed sample, was similar to that provided by its authors, and whether the selection of the sample did not affect the level of reliability of the questionnaire itself.

In the next step, the analysis of correlations among variables was carried out using Spearman's rank-order correlation coefficient. This coefficient measures the monotonic relationship among variables, which is more preferred to measure relationships for ordinal scales. The linear regression model was then used to test the hypotheses, which allowed for an assessment 
of relationships among all analyzed variables. This technique was used to explain the relationships among the examined variables.

\section{Independent variables}

The tools used to measure variables in the quantitative empirical research were those widely used in the literature. These measures were translated by the forward-back translation method.

In order to analyze market orientation (MO), a questionnaire ( $\alpha=0.94)$ developed by Gnizy, Baker, and Grinstein (2014) focusing on measuring market information acquisition (MIA) and market information dissemination (MID) of enterprises was applied. All items were measured using a 7-point Likert scale. MO reflects the degree to which firms rely on maximizing customer satisfaction and loyalty as an organizing principle of the firm. $\mathrm{MO}$ requires firms to proactively acquire, disseminate, and rely on market information when developing marketing strategies and tactics to be employed successfully. In the empirical studies, the values obtained through Cronbach's alpha values $(=0.898)$ showed very good reliability of this variable.

Market dynamism was understood as the rate of change of various elements in the market in which the enterprises operate, measured by changes in technology, competition, and customers. This questionnaire $(\alpha=0.73$ ) was used earlier by Wang, Senaratne, and Rafiq (2015). In our empirical studies, the values obtained by means of Cronbach's alpha values $(\alpha=0.856)$ showed very good reliability of this questionnaire. The selection of the sample did not reduce the level of its reliability.

\section{Dependent variable}

Firm performance is a dependent variable measured by three items of profitability, sales growth, and market share. This questionnaire $(\alpha=0.892)$ was used earlier by Keh, Nguyen, and Ng (2007). Respondents were asked to compare their firm's performance to their major competitors. All performance measures of the enterprises were subjective, i.e. according to the perception of the respondent. All items were measured using a 7-point Likert scale (1 - Much Weaker to 7-Much Better). Research studies by Khan, Xuehe, Atlas, and Khan (2019) mentioned that using subjective measures is a valid alternative when objective measures are not obtainable. What is important to note is that the values obtained by means of Cronbach's alpha values ( $\alpha=0.901$ ) showed very good reliability of this variable. The reliability of the questionnaire used was similar to that given by its authors, and the selection of the sample did not reduce the level of its reliability. 


\section{Control variable}

Businesses of a different size may exhibit different organizational and environmental characteristics, which in turn may influence performance. Therefore, this variable (firm size) was included as control.

\section{RESULTS}

\section{Descriptive statistics of the analyzed constructs according to the size of enterprises}

Another analysis of variables was made according to the size of enterprises using the criterion of the number of employees according to the ACT of 6 March 2018 - Entrepreneurs' Law, Journal of Laws of 2019, item 1292, art. 7. A pivot table was used in which the average levels of variables and the corresponding standard deviations, min., max., median, $\mathrm{Q}_{25}, \mathrm{Q}_{75}$, and $p$-value for individual sizes of enterprises are presented. A comparison of average levels of variables along with standard deviations and values of other categories presented separately for individual sizes of enterprises is shown in Table 2.

Table 2. Size of enterprises according to the number of employees and analyzed constructs: market orientation, market dynamism, and firm performance

\begin{tabular}{|c|c|c|c|c|c|c|c|c|c|}
\hline & & $\begin{array}{l}\text { Mean } \\
\text { value }\end{array}$ & $\begin{array}{l}\text { Standard } \\
\text { deviation }\end{array}$ & Min. & Q25 & Median & Q75 & Max. & p-value \\
\hline \multirow{3}{*}{$\begin{array}{l}\text { Market } \\
\text { orientation }\end{array}$} & from 1 to 9 & 4.32 & 1.24 & 1.50 & 3.60 & 4.50 & 5.20 & 6.70 & \multirow{3}{*}{0.253} \\
\hline & from 10 to 49 & 4.49 & 1.12 & 2.20 & 3.75 & 4.50 & 5.10 & 7.00 & \\
\hline & from 50 to 249 & 4.78 & 1.42 & 1.50 & 4.00 & 4.90 & 5.80 & 7.00 & \\
\hline \multirow{3}{*}{$\begin{array}{l}\text { Market } \\
\text { information } \\
\text { acquisition }\end{array}$} & from 1 to 9 & 4.36 & 1.39 & 1.60 & 3.40 & 4.40 & 5.40 & 7.00 & \multirow{3}{*}{$0.066 * *$} \\
\hline & from 10 to 49 & 4.71 & 1.16 & 2.00 & 4.00 & 4.70 & 5.50 & 7.00 & \\
\hline & from 50 to 249 & 5.04 & 1.64 & 1.40 & 3.80 & 5.20 & 6.20 & 7.00 & \\
\hline \multirow{3}{*}{$\begin{array}{l}\text { Market } \\
\text { information } \\
\text { dissemination }\end{array}$} & from 1 to 9 & 4.28 & 1.35 & 1.00 & 3.40 & 4.40 & 5.20 & 7.00 & \multirow{3}{*}{0.676} \\
\hline & from 10 to 49 & 4.27 & 1.25 & 2.00 & 3.20 & 4.20 & 5.20 & 7.00 & \\
\hline & from 50 to 249 & 4.52 & 1.41 & 1.60 & 3.80 & 4.60 & 5.20 & 7.00 & \\
\hline \multirow{3}{*}{$\begin{array}{l}\text { Market } \\
\text { dynamism }\end{array}$} & from 1 to 9 & 3.83 & 1.03 & 1.00 & 3.33 & 3.83 & 4.33 & 6.50 & \multirow{3}{*}{0.295} \\
\hline & from 10 to 49 & 3.97 & 1.29 & 1.33 & 3.08 & 4.17 & 5.00 & 6.67 & \\
\hline & from 50 to 249 & 3.61 & 1.01 & 1.67 & 3.00 & 3.67 & 4.33 & 5.33 & \\
\hline
\end{tabular}




\begin{tabular}{|c|c|c|c|c|c|c|c|c|c|}
\hline & & $\begin{array}{l}\text { Mean } \\
\text { value }\end{array}$ & $\begin{array}{l}\text { Standard } \\
\text { deviation }\end{array}$ & Min. & Q25 & Median & Q75 & Max. & p-value \\
\hline \multirow{3}{*}{$\begin{array}{l}\text { Speed of change } \\
\text { in technology } \\
\text { and competition }\end{array}$} & from 1 to 9 & 4.23 & 1.31 & 1.00 & 3.50 & 4.00 & 5.00 & 7.00 & \multirow{3}{*}{0.516} \\
\hline & from 10 to 49 & 4.43 & 1.37 & 1.50 & 3.50 & 4.75 & 5.50 & 7.00 & \\
\hline & from 50 to 249 & 4.31 & 1.40 & 1.00 & 4.00 & 4.50 & 5.00 & 7.00 & \\
\hline \multirow{3}{*}{$\begin{array}{l}\text { Unpredictability } \\
\text { of change in } \\
\text { technology and } \\
\text { competition }\end{array}$} & from 1 to 9 & 3.54 & 1.33 & 1.00 & 2.50 & 3.50 & 4.50 & 6.50 & \multirow{3}{*}{0.214} \\
\hline & from 10 to 49 & 3.65 & 1.45 & 1.00 & 2.50 & 4.00 & 4.75 & 7.00 & \\
\hline & from 50 to 249 & 3.12 & 1.23 & 1.00 & 2.00 & 3.50 & 4.00 & 5.50 & \\
\hline \multirow{3}{*}{$\begin{array}{l}\text { Uncertainty } \\
\text { of customer } \\
\text { behavior }\end{array}$} & from 1 to 9 & 3.74 & 1.13 & 1.00 & 3.00 & 4.00 & 4.50 & 6.50 & \multirow{3}{*}{0.343} \\
\hline & from 10 to 49 & 3.83 & 1.56 & 1.00 & 2.75 & 4.00 & 5.00 & 7.00 & \\
\hline & from 50 to 249 & 3.40 & 1.30 & 2.00 & 2.50 & 3.00 & 4.00 & 6.50 & \\
\hline \multirow{3}{*}{$\begin{array}{l}\text { Firm } \\
\text { performance }\end{array}$} & from 1 to 9 & 4.34 & 1.23 & 1.00 & 3.33 & 4.33 & 5.00 & 7.00 & \multirow{3}{*}{$0.039 *$} \\
\hline & from 10 to 49 & 4.63 & 1.03 & 1.00 & 4.00 & 4.50 & 5.33 & 7.00 & \\
\hline & from 50 to 249 & 4.90 & 1.23 & 1.00 & 4.33 & 5.33 & 5.67 & 6.33 & \\
\hline
\end{tabular}

The analysis of the results contained in Table 2 indicated that mediumsized enterprises are characterized by the highest market orientation (4.78 on average), while slightly lower market orientation is characteristic of micro and small enterprises (4.32 and 4.49, on average, respectively). However, small enterprises are the least diversified group, and medium-sized enterprises are the most diversified one in this respect. This is evidenced by the recorded values of standard deviation (SD) (1.12 and 1.42, respectively), indicating that the evaluation of the level of market orientation differed from the arithmetic mean by 1.12 points in the group of small enterprises and by 1.42 points in the group of medium-sized enterprises. In addition, $50 \%$ of micro and small enterprises rated their market orientation as not higher than 4.5 points. However, it should be taken into account that $25 \%$ of micro enterprises rated $\mathrm{MO}$ as not higher than 3.60 points and the other $75 \%$ of micro enterprises rated $\mathrm{MO}$ as not higher than 5.20 points. A similar level of $\mathrm{MO}$ was rated in the group of small enterprises, because $25 \%$ of small enterprises rated $\mathrm{MO}$ as not higher than 3.75 points, and $75 \%$ of small enterprises rated $\mathrm{MO}$ as not higher than 5.10 points. It is worth adding that $50 \%$ of medium-sized enterprises rated $\mathrm{MO}$ as not higher than 4.90 points, $25 \%$ of medium-sized enterprises rated it not higher than 4.00 points, while $75 \%$ of medium-sized enterprises believed that its MO level was not higher than 5.80 points. It is also noteworthy to add that micro and small enterprises showed a similar and slightly lower level of $\mathrm{MO}$ than medium-sized enterprises. This means that medium-sized enterprises with strong $\mathrm{MO}$ attach great importance to updating their knowledge about customers, competitors, and market 
conditions. In practice, this is manifested by the fact that they pay special attention and are sensitive to the main participants of the local environment, such as customers and competitors. However, these differences were statistically non-significant, as indicated by the values of means (see Table 2) and their level of significance.

Market dynamism measured by changes in technology, competition and customers was not extremely low or high from the enterprises' point of view. Nevertheless, changes in market dynamism were not identically evaluated. Micro and small enterprises were indicating a moderately dynamic environment (3.97 and 3.83, on average; SD: 1.29 and 1.03 points), while medium-sized enterprises perceived the environment as still a bit more stable (3.61, on average). At the same time, it is a group of least diversified enterprises in terms of evaluating the degree of market dynamism (SD: 1.01 points).

Moreover, $50 \%$ of small enterprises rated their MD as not higher than 4.17 points. Also noteworthy is that $25 \%$ of small enterprises rated MD as not higher than 3.08 points, and $75 \%$ of them rated MD as not higher than 5.00 points. In contrast, $50 \%$ of micro-enterprises rated their MD as not higher than 3.83 points. In addition, $25 \%$ of these enterprises rated MD as not higher than 3.33 points, and $75 \%$ of them rated MD as not higher than 4.33 points. Over $50 \%$ of medium-sized enterprises, in turn, rated their MD as not higher than 3.67 points. What is more, $25 \%$ of medium-sized enterprises rated MD as not higher than 3.00 points, and $75 \%$ of them rated MD as not higher than 4.33 points. But these differences were statistically non-significant.

The compilation of statistical data (in each group of analyzed enterprises) describing market dynamism and market orientation showed that these surveyed enterprises have higher than average MO levels in more stable and predictable markets. At that time, the degree of market dynamism was probably not high enough for these enterprises to have the need to develop dynamic capabilities more than the operational ones. The states of the analyzed phenomena indicated a moderately stable and predictable environment in which these enterprises had to develop market orientation more.

By continuing the analysis of statistical data, one may notice that the medium-sized enterprises rated their performance better than other organizations. For this group of enterprises, the performance was at the level of 4.90 points, on average; while, the standard deviation value equaled 1.23 points. In other words, medium-sized enterprises were characterized by slightly higher performance than micro and small enterprises $(4.63 ; 434$, on average). Standard deviations of micro- and medium-sized enterprises were identical and, therefore, indicated the same diversity of enterprises in these groups in terms of business results (1.23 points). The least diversified group while evaluating the results were small enterprises (1.03 points). Although 
these differences were relatively small, they were statistically significant, as indicated by the values of means (see Table 2 ) and their level of significance.

Therefore, it may be concluded that the financial performance of the analyzed enterprises was higher than that of their competitors. The better performance of the enterprise, when compared to its competitors, usually serves as an empirical indicator of competitive advantage (Schilke, 2014). This means that the analyzed enterprises, by achieving a better performance than the others, were also more successful than the others. In general, higher levels of financial performance were recorded in groups of larger enterprises than in those of smaller sizes. Therefore, in the next step, it was decided to recognize the relationship between the number of employees in a given enterprise and its performance.

The non-parametric Kruskal-Wallis H test was used to compare continuous variables among the analyzed groups. Statistically significant results obtained on that basis showed a difference in the distribution of a given variable among the groups being compared. It was confirmed by the Kruskal-Wallis $\mathrm{H}$ test $(\mathrm{p}<0.05)$ that financial performance was better evaluated in larger enterprises. The conducted post-hoc tests indicated differences between micro- and medium-sized enterprises while evaluating firm performance (Dunn, $p<0.05$ ). Table 3 shows the significance of pairwise comparisons.

Table 3. Size of enterprises and firm performance (post-hoc: by Dunn's test)

\begin{tabular}{lll}
\hline \multicolumn{2}{l}{ Number of employees and firm performance (pairwise comparisons: Dunn; $p<0.05$ ) } \\
\hline & from 1 to $\mathbf{9}^{*}$ & from 10 to 49 \\
\hline from 10 to 49 & 0.153 & \\
\hline from 50 to 249 & $\mathbf{0 . 0 1 6}$ & 0.153 \\
\hline Note: ${ }^{*}$ except for self-employment. &
\end{tabular}

In the next step, correlations among the variables appearing in the research model were being analyzed. A table for correlation of variables was prepared using Spearman's rank-order correlation coefficient. The following values of Spearman's rank-order correlation coefficient were used to determine the strength of correlations:

$0.00 \leq\left|r_{s}\right| \leq 0.29$ - no correlation - weak correlation

$0.30 \leq\left|r_{s}\right| \leq 0.49$ - moderate correlation

$0.50 \leq\left|r_{s}\right| \leq 0.69$ - strong correlation

$0.70 \leq\left|r_{s}\right| \leq 1.00$ - very strong correlation 
It was assumed that only statistically significant relationships would be analyzed. The results of correlations among the analyzed variables are presented in Table 4.

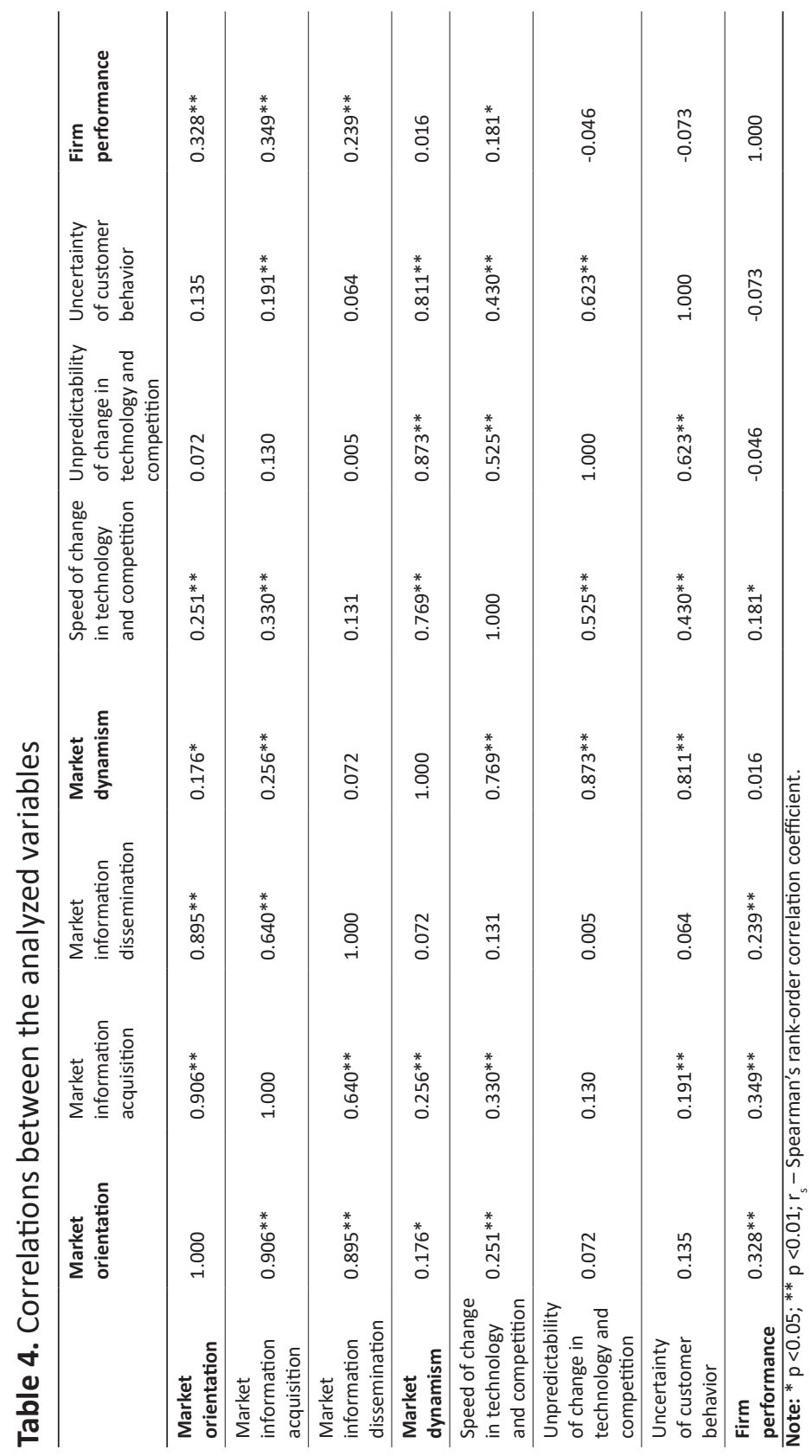

The Evolution of Strategic Management: Challenges in Theory and Business Practice Tomasz Kafel \& Bernard Ziębicki (Eds.) 
The analysis of data included in Table 4 indicated weak or moderate correlations among the variables in individual configurations. It may be noted that both market orientation dimensions were positively correlating with firm performance. However, the value of Spearman's rank-order correlation coefficient $\left(r_{s}=0.349\right)$ showed that the relationship between the market orientation dimension, i.e. market information acquisition and firm performance, was positive, had average strength, and was statistically significant $(p<0.01)$. Simultaneously, the correlation of the following market orientation dimension, i.e. market information dissemination and firm performance, was positive, though it was slightly weaker $\left(r_{s}=0.239, p<0.01\right)$. Positive, although weak $\left(r_{s}=0.176\right)$, correlation between market dynamism and market orientation could be observed, which was statistically significant $(p<0.05)$. Furthermore, positive and greatest $\left(r_{s}=0.330\right)$, correlation between speed of change in technology and competition (MD dimension) and market information acquisition ( $\mathrm{MO}$ dimension) could be observed, which was statistically significant $(p<0.01)$. The correlation analysis results indicated a weak, but positive, correlation between the first dimension of market dynamism, i.e. speed of change in technology and competition and firm performance $\left(r_{s}=0.181 ; p<0.05\right)$. Correlations between the two remaining dimensions of MD were not statistically significant.

The analysis of the correlations among individual dimensions of market dynamism encourages a deeper recognition and understanding of the existing market orientation-firm performance relationship in the context of market dynamism.

\section{Results of verification of research hypothesis}

In order to verify the $\mathrm{H} 1$ hypothesis, the linear regression model was used. The values of coefficients obtained for permanent effects in this model inform how much the expected value of explanatory variable changes and the unitary growth of a given predictor. The explanatory variable (predictor) is a variable in a statistical model on the basis of which the response variable is calculated. There are two explanatory variables in the model. The phenomenon which is being analyzed is, in turn, called a response variable (firm performance). Factors affecting its behavior are the above-mentioned explanatory variables (market orientation, market dynamism). The statistical significance of these coefficients was verified by a test based on the $t$ statistics. For all of the above-mentioned tests, $p<0.05$ indicated the statistical significance for the analyzed relationships. 
The evaluation of the impact of dynamism of the market in which enterprises operate in explaining the impact of market orientation on firm performance is dictated by the verification of the $\mathrm{H} 1$ hypothesis.

\section{H1: Market dynamism moderates the market orientation-firm} performance relationship; the positive effect of market orientation on firm performance is likely to be stronger under high market dynamism than under low market dynamism.

Due to the lack of significance of predictors, the results of the $\mathrm{H} 1$ hypothesis verification are presented only in the table. Importantly, a colon sign between $\mathrm{MO}$ and $\mathrm{MD}$ in Table 5 means the interaction between the factors included in the $\mathrm{H} 1$ hypothesis.

Table 5. Regression models

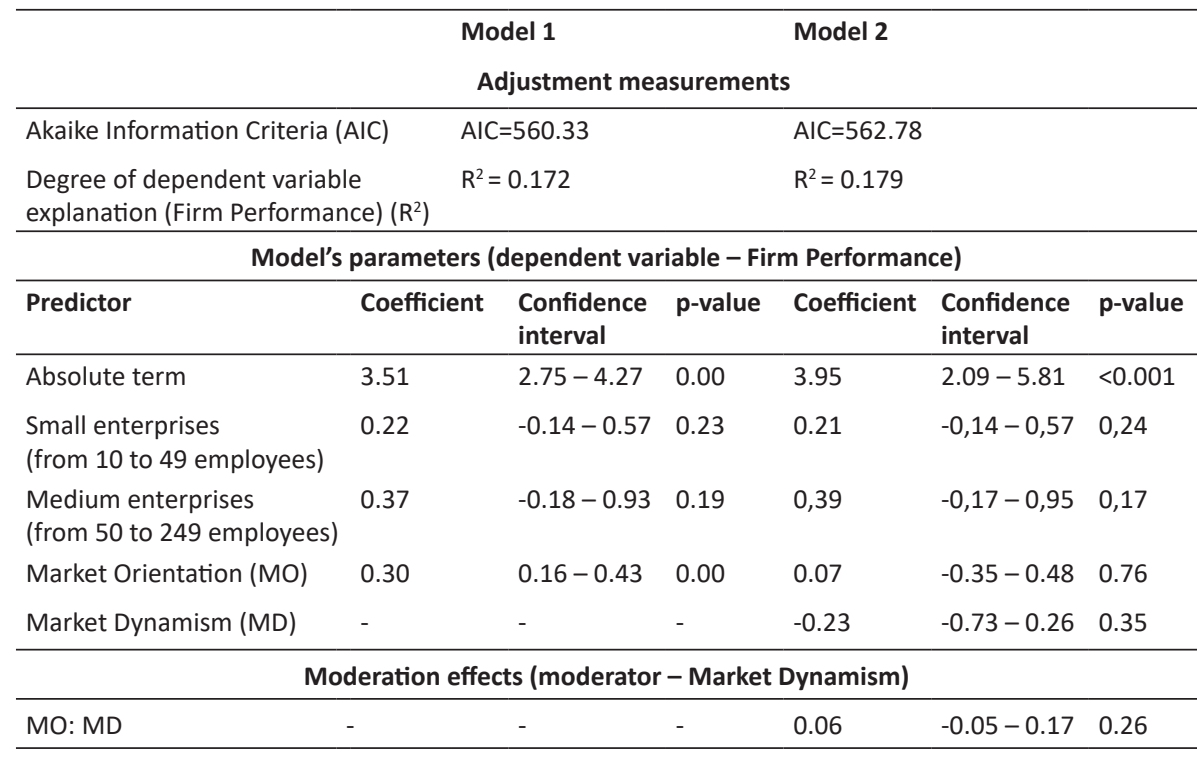

Models 1 and 2 in Table 5 were estimated based on the Akaike Information Criteria (AIC). The AIC for both models was similar, i.e. 560.33 for the first model and 562.78 for the second one. AIC levels for both models indicated acceptable matching levels. The lower the value of AIC, the better the predictive values of the model (Burnham \& Anderson, 2002, pp. 261304). Model 1 explained $17.2 \%$ of data variability $\left(R^{2}=0.172\right)$, while Model 2 explained $17.9 \%$ of data variability $\left(R^{2}=0.179\right)$, which is just a little more than in the case of Model 1 . The analysis of the models presented in Table 5 
has led to several conclusions. In the first model, only the market orientation was positively related to firm performance, and it only slightly explains the variability of the dependent variable. It has a small, although statistically significant, impact on firm performance (coefficient: $0.30 ; p=0.00$ ).

Secondly, the linear regression model (Model 2) did not support the thesis about the moderating role of market dynamism on the market orientation-firm performance relationship. None of the predictors showed statistical significance in Model 2. What is more, taking the market dynamism variable into account affects the quality of the model, and market dynamism itself adopts negative prediction indicators, which means that better firm performance in responding to changes in the level of market dynamism deteriorates the overall firm performance. The research, however, did not confirm whether market dynamism - a higher-order construct built from three first-order constructs, i.e. speed of change in technology and competition, unpredictability of change in technology and competition, uncertainty of customer behavior - raises the importance of market orientation in increasing firm performance and thus in achieving competitive advantage.

Thirdly, control variables were non-significant in both models. This shows that the introduction of two control variables and a moderator variable reduced the impact of market orientation on firm performance to a statistically insignificant level.

\section{DISCUSSION}

This research fits into the mainstream of scientific inquiry into the conditions in which market information acquisition (MIA) and market information dissemination (MID) of enterprises can improve or worsen their performance. Verification of the research hypothesis allowed for answering the question of how market orientation is explained by firm performance provided that a moderator in the form of market dynamism is applied. Already, at the stage of analyzing the data reflecting correlations among the variables, one may observe a negative effect of this variable, but it was not statistically significant (Table 4). The linear regression Model 2 (Table 5) indicated that introducing market dynamism as a moderator negatively impacts this model, making the previously significant predictor (market orientation) (Model 1 ; coefficient: $0.30 ; p=0.00$ ) lose statistical significance in explaining companies performance (Model 1; coefficient: $0.07 ; p=0.76$ ). Therefore, no significant role of the moderating variable, i.e. market dynamism on the market orientation - firm performance relationship was proved. 


\section{CONCLUSION}

The descriptive statistics of the analyzed variables allowed for determining market orientation, firm performance, market dynamism and their components, according to the size of MSMEs operating in technology parks in Poland, being under analysis. In the research sample, the enterprises were characterized by relatively high market orientation. At the same time, fairly high values of standard deviations of the individual dimensions of market orientation proved that not all enterprises in the sample had a high level of market orientation, as there were also those that had it at a much lower level than the others.

Moreover, the identified levels of individual dimensions of market dynamism indicated that these enterprises were generally functioning in a more stable or moderately dynamic market than in the conditions of high market dynamism. However, fairly high values of standard deviation of particular dimensions of market dynamism (speed of change in technology and competition, unpredictability of change in technology and competition, uncertainty of customer behavior) indicated that not all enterprises are equally able to perceive the pace of change in technology, competition, and customers. This means that among them, there are those that assess the conditions of their functioning in the market as more and definitely less stable. Tenant enterprises are not a homogeneous group in this respect.

Data analysis showed (Table 3) that larger enterprises consider their business operations much better than smaller ones. This means that the level of firm performance is related to the number of employees. These findings are an argument to treat an increase in the number of employees as a nonfinancial measure of organizational growth.

At the same time (Table 2), the financial performance achieved by the analyzed enterprises was slightly higher than the performance of their direct competitors. However, the high value of standard deviation showed that in this group of enterprises, there were those that achieved a small, but still at least some, advantage over competitors and those that had no competitive advantage or had performance similar to those achieved by their competitors.

Current research indicates that, in the conditions of a moderately changing environment (on average, such a level of market dynamism was occurring in the markets operated by enterprises operating in technology parks in Poland at the time of the quantitative empirical research), the analyzed enterprises, on average, put more emphasis on exploratory development than on operational learning about the market. These findings indicate that in such conditions, having an above-average level of market orientation allowed those enterprises to achieve a higher financial performance than their competitors. However, 
a fairly high level of standard deviations referring to the performance of enterprises in individual sizes of enterprises cannot be overlooked.

Further comparative research on inter-relationships among different strategic orientations and firm performance in many contexts is, thus, important. In the international arena, this research can be repeated in the context of enterprises that introduce current products to new markets, new products to existing markets, as well as new products to new markets. The importance of these issues for strategic management increases along with the progress of managerial staff on increasing the efficiency of business organizations. What is more, the results of the research are the basis for statements on the effectiveness of the surveyed MSMEs functioning in TPs in Poland. However, as the research sample is not representative, it is not possible to generalize these research findings on the entire MSMEs' population operating in technology parks in Poland.

\section{Acknowledgment}

Funding is gratefully acknowledged. The study has been performed as part of a research project financed by the Jan Kochanowski University in Kielce, no. 20064. We would like to thank the two anonymous reviewers for providing constructive feedback that greatly improved this article.

\section{References}

Abbua, H.R., \& Gopalakrishna, P. (2021). Synergistic effects of market orientation implementation and internalization on firm performance: Direct marketing service provider industry. Journal of Business Research, 125, 851-863. https://doi.org/10.1016/j.jbusres.2019.06.004

Act of 6 March 2018 - Entrepreneurs' Law, Journal of Laws of 2019, item 1292 , art. 7.

Atuahene-Gima, K., Slater, S.F., \& Olson, E.M. (2005). The contingent value of responsive and proactive market orientations for new product program performance. Journal of Product Innovation Management, 22(6), 464482. https://doi.org/10.1111/j.1540-5885.2005.00144.x

Baker, W., \& Sinkula, J. (2005). Market orientation and the new product paradox. Journal of Product Innovation Management, 22(6), 483-502. https://doi.org/10.1111/j.1540-5885.2005.00145.x

Barreto, I. (2010). Dynamic capabilities: A review of past research and agenda for future research. Journal of Management, 36(1), 256-280. https://doi. org/10.1177\%2F0149206309350776

Barney, J. (1991). Firm resources and sustained competitive advantage. Journal of Management, 17(1), 99-120. https://doi.org/10.1177\% 2F014920639101700108 
Bitkowska, A. (2020). The relationship between business process management and knowledge management - selected aspects from a study of companies in Poland, Journal of Entrepreneurship, Management and Innovation, 16(1), 169-193. https://doi.org/10.7341/20201616

Burnham, K.P., \& Anderson, D.R. (2002). Model Selection and Multimodel Inference: A Practical Information-Theoretic Approach (2nd ed). New York: Springer.

Cyfert., Sz., \& Krzakiewicz, K. (2017). Procesy kształtowania dynamicznych zdolności w polskich przedsiębiorstwach. In K. Krzakiewicz \& Sz. Cyfert (Eds.), Strategiczny wymiar dynamicznych zdolności polskich przedsiębiorstw (pp. 329-342). Poznań: Wydawnictwo UEP.

Dyduch, W. (2017). Strategiczny projekt wspierający rozwój zdolności dynamicznych. In K. Krzakiewicz \& Sz. Cyfert (Eds.), Strategiczny wymiar dynamicznych zdolności polskich przedsiębiorstw (pp. 341-366). Poznań: Wydawnictwo UEP.

Dyduch, W. (2019). Entrepreneurial strategy stimulating value creation: Conceptual findings and some empirical tests. Entrepreneurial Business and Economics Review, 7(3), 65-82. https://doi.org/10.15678/ EBER.2019.070304

Freiling, J. (2015). Business model innovation - A concept between organizational renewal and industry transformation. Journal of Entrepreneurship, Management and Innovation, 11(1), 3-10. https://doi. org/10.7341/20151111

Gancarczyk, M., \& Zabala-Iturriagagoitia, J.M. (2015). The process of the growth of small and medium-sized enterprises (SMEs). Journal of Entrepreneurship, Management and Innovation, 11(1), 3-10. https://doi. org/10.7341/20151141

Gnizy, I., Baker, W.E., \& Grinstein, A. (2014). Proactive learning culture: A dynamic capability and key success factor for SMEs entering foreign markets. International Marketing Review, 31(5), 477-505. https://doi. org/ 10.1108/IMR-10-2013-0246

Gupta, V.H., Gizem, A., \& Dutta, D.K. (2019). Market orientation research: a qualitative synthesis and future research agenda. Review of Managerial Science, 13(4), 649-670. https://doi.org/10.1007/s11846-017-0262-z

Hakala, H. (2011). Strategic orientations in management literature: Three approaches to understanding the interaction between market, technology, entrepreneurial and learning orientations. International Journal of Management Reviews, 13(2), 199-217. https://doi. org/10.1111/j.1468-2370.2010.00292.x

Harbat, J., Kotowski, J., Mikulec, A., Mirończuk A., Dąbrowski, D., \& Pabijanek, E. (2018). Activity of enterprises with up to 9 persons employed in 2016. Retrieved from http://www.stat.gov.pls

Hessels, J., \& Parker, S.C. (2013). Internationalization and growth: a crosscountry analysis of European SMEs. Journal of World Business, 48(1), 137-148. https://dx.doi.org/10.1016/j.jwb.2012.06.014 
Hult, T., Snow, C., \& Kandemir, D. (2003). The role of entrepreneurship in building cultural competitiveness in different organizational types. Journal of Management, 29(3), 401-426. https://doi.org/10.1016/ S0149-2063_03_00017-5

İpek, I., \& Bıçakcıoğlu-Peynirci, N. (2020). Export market orientation: An integrative review and directions for future research. International Business Review, 29(4). https://doi.org/10.1016/j.ibusrev.2019.101659

Kara, A., Spillan, J., \& DeShields, O. (2005). The effect of a market orientation on business performance: A study of small-sized service retailers using MARKOR scale. Journal of Small Business Management, 43(2), 105-118. https://doi.org/10.1111/j.1540-627x.2005.00128.x

Kamasak, R., Yavuz, M., \& Altuntas, G. (2016). Is the relationship between innovation performance and knowledge management contingent on environmental dynamism and learning capability? Evidence from a turbulent market. Business Research, 9, 229-253. https://doi. org/10.1007/s40685-016-0032-9

Karna, A., Richter, A., \& Riesenkampff, E. (2016). Revisiting the role of the environment in the capabilities - financial performance relationship: A meta-analysis. Strategic Management Journal, 37, 1154-1173. https:// doi.org/10.1002/smj.2379

Keh, H.T., Nguyen, T.T.M., \& Ng, H.P. (2007). The effects of entrepreneurial orientation and marketing information on the performance of SMEs. Journal of Business Venturing, 22(4), 592-611. https://doi.org/10.1016/j. jbusvent.2006.05.003

Khan, K.U., Xuehe, Z., Atlas, F., \& Khan, F. (2019). The impact of dominant logic and competitive intensity on SMEs performance: A case from China, Empirical paper. Journal of Innovation \& Knowledge, 4, 1-11. https://doi. org/10.1016/j.jik.2018.10.001

Kirca, A.H., Jayachandran, S., \& Bearden, W.O. (2005). Market orientation: A meta-analytic review and assessment of its antecedents and impact on performance. Journal of Marketing, 69(2), 24-41. https://doi. org/10.1509/jmkg.69.2.24.60761.

Kohli, A.K., \& Jaworski, B.J. (1990). Market orientation: The construct, research propositions, and managerial implications. Journal of Marketing, 54(2), 1-18. https://dx.doi.org/10.2307/1251866

Kmieciak, R., \& Michna, A. (2012). Relationship between knowledge management and market orientation in SMEs. Proceedings of the Management, Knowledge and Learning International Conference. Retrieved from https://www.issbs.si/press/ISBN/978-961-6813-10-5/ papers/ML12_055.pdf

Lasocki, B., \& Skrzek-Lubasińska, M. (2016). Samozatrudnienie w Polsce - problemy definicyjne, dostępność danych i ich interpretacja. Wiadomości Statystyczne, 7(662), 1-15. 
Li, D., \& Liu, J. (2014). Dynamic capabilities, environmental dynamism, and competitive advantage: Evidence from China. Journal of Business Research, 67, 2793-2799. https://doi.org/10.1016/j.jbusres.2012.08.007

Narver, J.C., \& Slater, S.F. (1990). The effect of a market orientation on business profitability. Journal of Marketing, 54(4), 20-35. https://doi. org/10.2307/1251757

Michna, A. \& Kmieciak, R. (2012). Orientacja rynkowa a zarządzanie wiedzą w kontekście rozwoju i wzrostu małych i średnich przedsiębiorstw. Zeszyty Naukowe Politechniki Ślqskiej. Seria: Organizacja i Zarzq̨dzanie, 60(1871), 203-216.

McKenny, A.F., Short, J.C., Ketchen Jr., D.J., Payne, G.T., \& Moss, T.W. (2018). Strategic entrepreneurial orientation: Configurations, performance, and the effects of industry and time. Strategic Entrepreneurship Journal, 12, 504-521. https://doi.org/10.1002/sej.1291

Mu, J.E., Thomas, G., Peng, A., \& Di Benedetto, A. (2017). Strategic orientation and new product development performance: The role of networking capability and networking ability. Industrial Marketing Management, 64(7), 187-201. https://doi.org/10.1016/j.indmarman.2016.09.007

Petrus, B. (2019). Environmental dynamism: the implications for operational and dynamic capabilities effects. Management Sciences, 24(1), 28-36.

Rigtering, J.P.C., Kraus, S., Eggers, F., \& Jensen, S.H. (2014). A comparative analysis of the entrepreneurial orientation/growth relationship in service firms and manufacturing firms. The Service Industries Journal, 34(4), 275-294. https://doi.org/10.1080/02642069.2013.778978

Schilke, O. (2014). On the contingent value of dynamic capabilities for competitive advantage: The nonlinear moderating effect of environmental dynamism. Strategic Management Journal, 35(2), 179-203. https://doi. org/10.1002/smj.2099

Soniewicki, M., \& Paliszkiewicz, J. (2019). The importance of knowledge management processes for the creation of competitive advantage by companies of varying size. Entrepreneurial Business and Economics Review, 7(3), 43-63. https://doi.org/ https://doi.org/10.15678/ EBER.2019.070303

Wach, K. (2017). Exploring the role of ownership in international entrepreneurship: How does ownership affect internationalisation of Polish firms? Entrepreneurial Business and Economics Review, 5(4), 205224. http://doi.org/10.15678/EBER.2017.050410

Wang, C.L., Senaratne, Ch., \& Rafiq, M. (2015). Success traps, dynamic capabilities and firm performance. British Journal of Management, 26(1), 26-44. https://doi.org/10.1111/1467-8551.12066

Wales, W., Beliaeva, T., Shirokova, G., Stettler, T.R., \& Gupta, V.K. (2020). Orienting toward sales growth? Decomposing the variance attributed to three fundamental organizational strategic orientations. Journal of Business Research, 109, 498-510. https://doi.org/10.1016/j. jbusres.2018.12.019 
Wójcik-Karpacz, A. (2017). Orientacja przedsiębiorcza a wynik firmy. Problem pomiaru wyniku. Studia i Prace Kolegium Zarzqdzania i Finansów, 153, 143-160.

Wójcik-Karpacz, A. (2019). Zdolności organizacyjne w kontekście wyników przedsiębiorstwa. Aspekty teoretyczne i wyniki badań empirycznych. Warszawa: Wydawnictwo Naukowe PWN.

Zakrzewski, R., \& Skowrońska, A. (June 2019). Raport o stanie sektora małych $i$ średnich przedsiębiorstw w Polsce. Warszawa: Polska Agencja Rozwoju Przedsiębiorczości. Retrieved from https://www.parp.gov.pl/storage/ publications/pdf/Raport-o-stanie-sektora_20191209.pdf

\begin{abstract}
Abstrakt
Cel: Celem artykułu jest określenie roli dynamizmu rynkowego $w$ relacji między orientacja rynkowq a wynikami mikro-, matych i średnich przedsiębiorstw (MMŚP) działajacych w parkach technologicznych (PT) w Polsce. Metodyka: Do przeprowadzenia ilościowych badań empirycznych wykorzystano dwie metody CAWI i PAPI. Próba badawcza obejmowała MMŚP działajqce w parkach technologicznych w Polsce. Artykut jest odpowiedziq na potrzebę systematycznego badania modeli między orientacja rynkowq a wynikami firm. Wyniki: Wyniki badań daja wglad w poziom orientacji rynkowej i wyników analizowanych MMŚP działajq̨cych w parkach technologicznych w Polsce. Stwierdzono, że MMŚP w próbie badawczej nie stanowity pod tym względem jednorodnej grupy. Udowodniono, że orientacja rynkowa jest istotnym stymulatorem wyników firm, podczas gdy dynamizm rynkowy nie został sklasyfikowany jako moderator relacji orientacja rynkowa - wyniki firmy. Implikacje dla teorii i praktyki: Badanie to wnosi wkład w zarzqdzanie strategiczne poprzez identyfikację kluczowej roli orientacji rynkowej dla przedsiębiorstw, które chcq odnieść korzyści z tego typu orientacji strategicznej. Udowodniono istotna rolę predyktora - orientacji rynkowej w ksztattowanie wyników mikro-, małych i średnich przedsiębiorstw działajq̨cych w PT w Polsce. W praktyce oznacza to, że zwiększenie poziomu orientacji rynkowej sprzyja poprawie pozytywnie ocenianych wyników finansowych. Oryginalność i wartość: Nasze badanie przeprowadzone w MMŚP działajqqcych w parkach technologicznych w Polsce wzbogaca i uzupełnia wiedzę na temat orientacji rynkowej jako zjawiska o charakterze uniwersalnym, ponieważ dotyczy także mniejszych organizacji biznesowych.

Słowa kluczowe: orientacja rynkowa, dynamizm rynku, wyniki firm, park technologiczny, mikro, mate i średnie przedsiębiorstwa, MMŚP
\end{abstract}

\title{
Biographical notes
}

Anna Wójcik-Karpacz is Full Professor of social sciences. She holds a habilitated doctor of economic sciences in the field of management sciences. She is also an employee of the Chair of Management at the Jan Kochanowski University in Kielce. She has been a manager and contractor in national and international research projects, as well as an Expert of the Polish Business and Innovation Centers Association. Her scientific interests relate to 
entrepreneurship, entrepreneurial orientation, and organizational strategic orientations. She is the author and co-author of over 100 scientific texts.

Jarosław Karpacz is Full Professor of social sciences. He holds a habilitated doctor of economic sciences in the field of management sciences. He is also an employee of the Chair of Management at the Jan Kochanowski University in Kielce, as well as a manager and contractor in research projects financed by the National Science Center. His research focuses on entrepreneurship, entrepreneurial orientation, and strategic management.

Joanna Rudawska is Assistant Professor in the Chair of Management at the Faculty of Law and Social Sciences of the Jan Kochanowski University. In her research, she focuses on innovation and entrepreneurship entities, strategic orientations of companies, technology transfer. She is a member of the Polish Business and Innovation Centers Association.

\section{Conflicts of interest}

The authors declare no conflict of interest.

\section{Citation}

Wójcik-Karpacz, A., Karpacz, J., \& Rudawska, J. (2021). The impact of market orientation on the performance of MSMEs operating in technology parks: The role of market dynamism. Journal of Entrepreneurship, Management and Innovation, 17(2), 29-52. https://doi.org/10.7341/20211722 